Note

\section{Purification of NAD-dependent 1,2-Propanediol Dehydrogenating Enzyme from Microcyclus eburneus}

\section{Takumi Kawagishi, Naomichi Nishio, * Ryuichi Matsuno and Tadashi Kamikubo}

\author{
Department of Food Science and Technology, \\ Faculty of Agriculture \\ Kyoto University, Sakyo-ku, Kyoto \\ * Department of Fermentation Technologv, \\ Faculty of Engineering, Hiroshima University. \\ Sendamachi, Hiroshima
}

Received November 5, 1979

In the previous paper, "we reported the presence of NAD-dependent 1,2-propanediol dehydrogenating enzyme in the cells of Microcyclus eburneus grown on 1,2propanediol under aerobic conditions, and also reported that the enzyme activity was separated into two fractions, namely enzyme I and II on DEAE-Sephadex A-25 column chromatography.

This paper deals with further purification of the enzyme II by affinity chromatography, and estimation of molecular weights of whole enzyme II and its subunit by gel filtration and disc electrophoresis.

Microcyclus eburneus ATCC 21373 was cultivated by the same procedures as those previously mentioned under aerobic conditions. ${ }^{21}$ Preparation of cell-free extract and assay of the enzyme activity were done in the same way as previously mentioned. ${ }^{1 /}$ Protein was estimated by the method of Lowry et al ${ }^{3 /}$ Disc electrophoresis on polyacrylamide gels was carried out by the methods of Ornstein et $a l^{4 /}$ and Davis et $a b^{53}$ Molecular weight of enzyme was estimated according to the method of Andrews ${ }^{6}$ using gel filtration on Sephadex G-200. Molecular weight was also estimated according to the methods of Schwartz and Rorder $^{7 /}$ using electrophoresis on SDS polyacrylamide gels. The standard enzymes used were catalase (mol wt: 190,000), RNA polymerases (mol wt: 165,000; 155,000; $90,000,40,000), \gamma$-globulins $(160,000 ; 75,000 ; 50,000 ;$ $22,000)$, bovine serum albumins $(130,000 ; 65,000)$, chicken egg albumin $(45,000)$, pepsin $(36,000)$ and lysozyme $(14,400)$.

An affinity chromatography on blue dextranpolyacrylamide gels was carried out by the method of Kopperschläger et al. ${ }^{81}$ using blue dextran fixed with $10^{\circ} \%$ polyacrylamide gel.

The enzyme II was purified according to the procedures as follows: Enzyme II was separated from enzyme I by the same procedure as mentioned previously (protamine treatment, ammonium sulfate fractionation, DEAE-Sephadex A-25 column chromatography). The fraction of enzyme II was passed through hydroxylapatite column. The effluent was applied to a blue dextran polyacrylamide gel column $(2.5 \times 12 \mathrm{~cm})$ preliminarily equilibrated with $0.01 \mathrm{M}$ sodium phosphate buffer $(\mathrm{pH} 7.3)$ and eluted with $0.01 \mathrm{M}$ sodium phosphate buffer ( $\mathrm{pH} 7.3$ ) containing $1 \mathrm{~mm}$ NAD. The active fractions were collected, concentrated by collodion bag and dialyzed against $0.01 \mathrm{~m}$ sodium phosphate buffer (pH 7.3). The purification processes are summarized in Table I. The enzyme II was purified about 330 -fold at the step of affinity chromatography on blue dextran polyacrylamide gels.

The purified enzyme II was electrophoretically homogeneous as shown in Fig. 1.

The molecular weight of this enzyme was estimated to be 155,000 by gel filtration using Sephadex G-200 column as shown in Fig. 2. The molecular weight also estimated by SDS-polyacrylamide gel electrophoresis was 38,000 as shown in Fig. 3. Consequently, NAD-dependent 1,2propanediol dehydrogenase II seems to consist of four identical subunits of molecular weight of 38,000 .

Table I. Purification of 1,2-Propanediol Dehydrogenase II from the Cells of Mictocyclus eburneus Grown ON 1,2-Propanediol AEROBICALLY

\begin{tabular}{|c|c|c|c|c|c|}
\hline Purification step & $\begin{array}{l}\text { Specific }^{a} \\
\text { activity }\end{array}$ & Purification & $\begin{array}{c}\text { Total }^{b} \\
\text { activity }\end{array}$ & $\begin{array}{l}\text { Yield } \\
(\%)\end{array}$ & $\begin{array}{c}\text { Protein } \\
\text { (mg) }\end{array}$ \\
\hline Crude extract & 110 & 1.0 & 79,000 & 100 & 718 \\
\hline Protamine sulfate & 150 & 1.4 & 66,000 & 83 & 440 \\
\hline Ammonium sulfate & 190 & 1.7 & 58.200 & 73 & 306 \\
\hline DEAE-Sephadex A-25 & 2,000 & 19 & 8,400 & 10.6 & 4.2 \\
\hline Hydroxylapatite & 9,500 & 86 & 6,700 & 8.5 & 0.7 \\
\hline $\begin{array}{l}\text { Blue dextran } \\
\text { polyacrylamide }\end{array}$ & 36,600 & 333 & 3,660 & 4.6 & 0.1 \\
\hline
\end{tabular}

- Specific activity is expressed as nmol of NADH formed per min per mg protein.

$b$ Total activity is expressed as nmol of NADH formed per min. 
$\leftarrow$ Enzyme II

$\leftarrow$ BPB

FIG. 1. Polyacrylamide Gel Electrophoresis of 1,2Propanediol Dehydrogenase II Preparation.

The electrophoresis was carried out in $7.5 \%$ gel at $\mathrm{pH} 8.3$ at $2 \mathrm{~mA}$. The gels were stained with $0.25 \%$ Coomassie Brilliant Blue R. BPB, bromophenol blue.

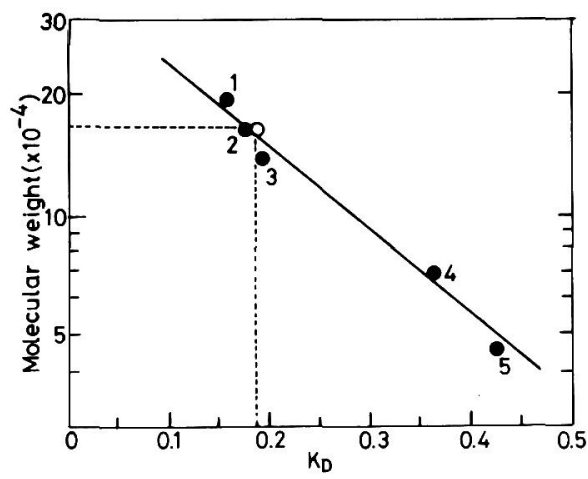

FIG. 2. Molecular Weight Estimation of 1,2Propanediol Dehydrogenase II by Gel Filtration on Sephadex G-200.

Standard proteins: 1, catalase; 2, $\gamma$-globulin; 3 , bovine serum albumin, dimer; 4 , bovine serum albumin, monomer; 5, chicken egg albumin. $K_{\mathrm{D}}$ : Distribution coefficient.

A column of $1.5 \times 90 \mathrm{~cm}$ was used.

For elution, sodium phosphate buffer ( $\mathrm{pH} 7.3)$ was used. Elution was made at $5 \mathrm{ml} / \mathrm{hr}$.

Acknowledgment. We wish to thank Drs. Yukiko Sasaki and Hideyuki Goto of Kyoto University for their kind advice and suggestions.

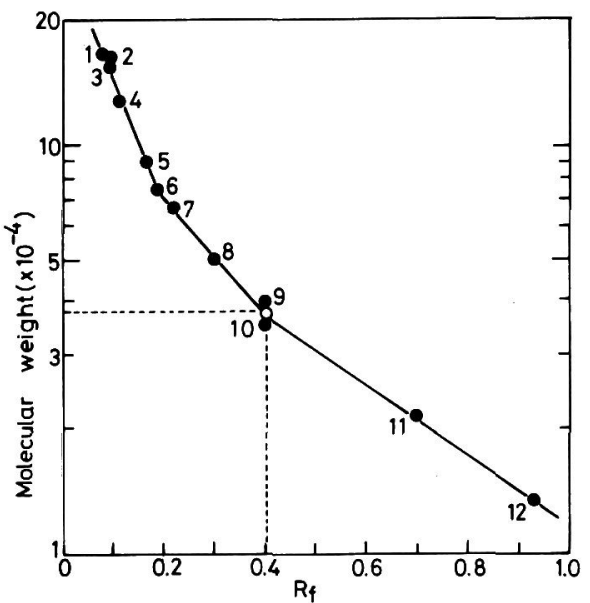

FIG. 3. Molecular Weight Estimation of 1,2Propanediol Dehydrogenase II by SDS-Polyacrylamide Gel Electrophoresis.

A solution containing $0.125 \mathrm{M}$ Tris- $\mathrm{HCl}$ buffer $(\mathrm{pH} 6.8)$, $6 \%$ SDS, $20 \%$ glycerol, $10 \%$ mercaptoethanol, $0.01 \%$ bromophenol blue and a sample (ca. $10 \mu \mathrm{g}$ of protein) were applied onto $12 \%$ polyacrylamide gels containing $0.1 \%$ SDS and then subjected to the electrophoresis at $\mathrm{pH}$ 8.3 of Tris-glycine buffer containing $0.1 \%$ SDS at $2 \mathrm{~mA}$. After then, the gels were stained with $0.25 \%$ Coomassie Brilliant Blue R.

Standard proteins: 1, E. coli RNA polymerase; $2, \gamma$ globulin; 3, E. coli RNA polymerase; 4, bovine serum albumin, dimer; 5, E. coli RNA polymerase; $6, \gamma$-globulin; 7, bovine serum albumin, monomer; $8, \gamma$-globulin; $9, E$. coli RNA polymerase; 10, pepsin; 11, $\gamma$-globulin; 12, lysozyme

\section{REFERENCES}

1) N. Nishio, T. Kawagishi, R. Matsuno and T. Kamikubo, Agric. Biol. Chem., 42, 1095 (1978).

2) N. Nishio, M. Tanaka, R. Matsuno and T. Kamikubo, J. Ferment. Technol., 55, 200 (1977).

3) O. H. Lowry, N. T. Rosenbrough, A. L. Farr and R. J. Randall, J. Biol. Chem., 193, 265 (1951).

4) L. Ornstein, Ann. New York Acad. Sci., 121, Art 2, 321 (1964).

5) B. J. Davis, Ann. New York Acad. Sci., 121, Art 2, 404 (1964).

6) P. Andrews, Biochem. J., 91, 222 (1964).

7) L. B. Schwartz and R. T. Roeder, J. Biol. Chem., 249, 5898 (1974).

8) G. Kopperschläger, W. Diezel, R. Freyer, S. Liebe and E. Hofmann, Eur., J. Biochem., 22, 40 (1971). 